Bond University

Research Repository

\title{
Bank Risk and National Governance in Asia
}

\author{
Williams, Barry
}

Licence:

CC BY-NC-ND

Link to output in Bond University research repository.

Recommended citation(APA):

Williams, B. (2012). Bank Risk and National Governance in Asia. Poster session presented at Research Week 2012, Gold Coast, Queensland, Australia.

\section{General rights}

Copyright and moral rights for the publications made accessible in the public portal are retained by the authors and/or other copyright owners and it is a condition of accessing publications that users recognise and abide by the legal requirements associated with these rights.

For more information, or if you believe that this document breaches copyright, please contact the Bond University research repository coordinator. 
